\title{
REPORT FROM THE XV HISTORICAL-LEGAL CONFERENCE REGISTERED UNDER NO. 139/N CONDUCTED WITH THE AID OF FUNDS FOR ORIGINAL RESEARCH 2037/W/IHPP/10 AND FUNDS FROM THE DEAN FOR PART-TIME STUDIES
}

\author{
JACEK PRZYGODZKI ${ }^{*}$
}

From 22.09.2011 through 24.09.2011 the XV annual conference and assembly of Historians of the State and Law was held in Jugowice. Alongside academics and doctoral students of the Institute of the History of the State and Law, participants included guests from around the country.

On the conference's first day, 22.09.2011, sessions were held in the afternoon and evening from 15.00 to 19.30, and on 23.09.2011 the academic session was continued through the morning hours. Conference participants presented 14 papers dedicated to the subject of The family and its rights. The papers presented explored the legal position of the family and marriage law from ancient times until the present, providing an excellent contribution to the enrichment of participants' historical and legal knowledge while showing the influences of historical thought on the modern study of family law. The speakers' presentations provoked lively discussion among the conference participants, and the conclusions of the discussants constitute an excellent addition to the content of the papers.

Expanded and supplemented conference speeches will constitute the basis for articles to be published in book format funded by the Institute of History of the State and Law.

DOI: $10.2478 /$ wrlae-2013-0034

* PhD; LLM; Institute of the History of the State and Law, Wroclaw University; jacpr@prawo.uni.wroc.pl 